\title{
検索エンジンを用いた関係の重みづけ
}

\section{Weighting Relations Using Web Search Engine}

\author{
岡 瑞起 \\ Mizuki Oka \\ 東京大学 知の構造化センター \\ Center for Knowledge Structuring, The University of Tokyo \\ mizuki@cks.u-tokyo.ac.jp, http://web.mac.com/mizuki.oka/ \\ 松尾 豊 \\ 東京大学大学院 工学系研究科 \\ Graduate School of Engineering, The University of Tokyo \\ matsuodbiz-model.t.u-tokyo.ac.jp, http://ymatsuo.com/
}

keywords: Web mining, Relation extraction, Relation weighting, Search engine

\section{Summary}

Measuring the weight of the relation between a pair of entities is necessary to use social networks for various purposes. Intuitively, a pair of entities has a stronger relation than another. It should therefore be weighted higher. We propose a method, using a Web search engine, to compute the weight of the relation existing between a pair of entities. Our method receives a pair of entities and various relations that exist between entities as input. It then outputs the weighted value for the pair of entities. The method explores how search engine results can be used as evidence for how strongly the two entities pertain to the relation.

\section{1. は じめに}

インターネットの発展や，樣々なツールの普及により， 誰でも簡単に Web コンテンツを作成することが可能と なっている近年, 日々大量の情報が生産, 蓄積されてい る . 検索エンジンは , キーワードベースで , このような 大量の情報に簡単にアクセスすることを可能としており， もはや日常生活には無くてはならないツールとなってき ている . 同時に、検索エンジンの上位に表示されなけれ ば，あなたのホームページは存在しないも同じ」 ${ }^{* 1}$ とい う表現か話題となったりしている.実際 , 膨大な数のWeb ページが存在し, 増加し続けている状況の中, 検索エン ジンの上位に表示されないページにアクセスすることは 難しい.このような状況は, 特に, 企業にとっては, 検索 エンジンの検索結果の上位に表示されるかどうかは，極 めて重要な問題であり, 検索エンジン最適化に樣々な手 法を利用して対策を講じている [Jones 08].

一方, Web からのさらなる知識獲得のために, 大量の 情報から, 固有表現抽出 [Sekine 07], 属性抽出や関係抽 出を行う研究が盛んに行われている [Kudoh 05, Matsuo 07, Banko 08] .さらに, Web から抽出された関係が総体 として織り成すネットワーク構造を分析し, 関係構造の 中に隠された知見を読み解く社会ネットワーク分析と呼 ばれる研究が注目を集めている．ソーシャルネットワー キングサービスの分析 [松尾 07] , 企業間ネットワーク

*1 2007年の NHK 特集 (http://www.nhk.or.jp/special/onair/070121. html) で Google が取り上げられ，番組の中で使われた .
の抽出や分析 [金 05] , 研究者ネットワークの抽出や分 析 [Matsuo 06] など, Web から抽出される多樣なデータ に対して , 社会ネットワーク分析の手法が適用可能であ ることが示されている．

Web から抽出される関係が構成するネットワーク構造 を分析することで, Web のリンク関係から重要なページ を発見したり [Brin 98], 特定の 2 人の人間をつなぐ知り 合い関係のパスを抽出したり [Kautz 97]，あるトピック に関する Web 上のコミュニティ [Kumar 99] を発見した りすることができる．関係の間の強さを知ることは，抽 出された関係を用いて, ネットワークを構筑したり, 分 析したりする際に，必要不可欠である．例えば，特定の 人間をつなぐ関係パスを探索する際に，より強い関係を 持つ人物を通すパスを提示することにより，より確実に 目的の人物にたどり着ける可能性が高くなる .

本論文では，検索エンジンを用いて，2つの語の間の関 係の重みづけを行う手法を提案する . 関係の重みづけの 対象のなる人や，会社名といった語を，本論文では，エ ンティティ，光して関係の重みづけの対象となる $2 つ の$ エンティティの対をエンティティペアと呼ぶ . 関係の重 みづけにあたって, エンティティペアの 1 つのエンティ ティと，キーワードをクエリとして与えたときに，もう 片方のエンティティが検索結果の上位に現れるかという 点に着目する . 検索エンジンの結果とキーワードの一般 性を統計的に処理することでエンティティペアの重みづ けを行う.

本論文の構成は以下である . 2 章ではエンティティペ 


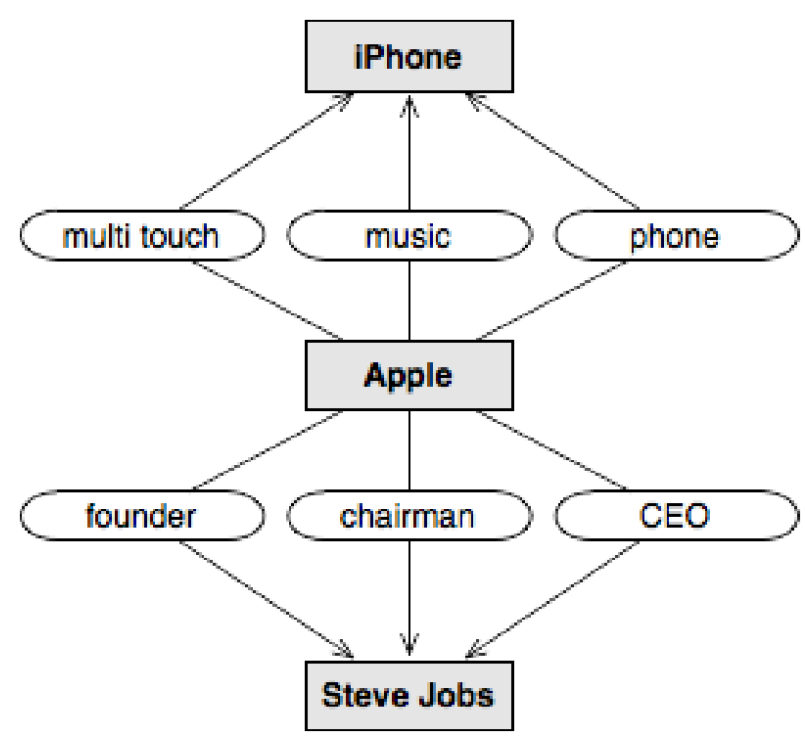

図 1 連想語によって引き出されるエンティティ間の関係

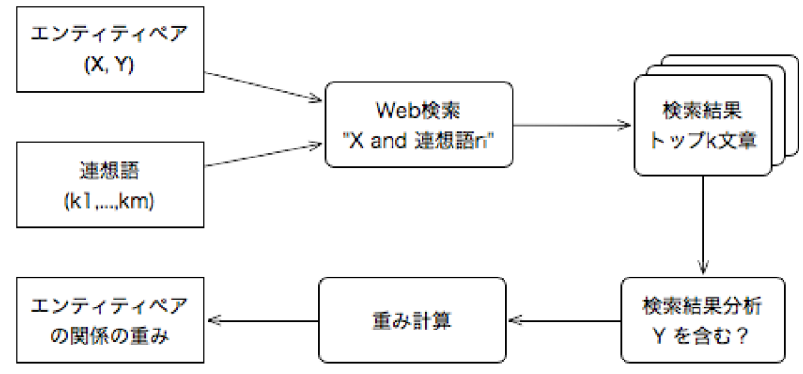

図 2 重みづけの流れ.

アの重みづけの手法を述べる．3 章では評価を行う．4 章 では考察と議論を行う. 5 章て関連研究を述べ, 最後に 6 章においてまとめを行う .

\section{2. 検索エンジンを用いた関係の重みづけ手法}

\section{$2 \cdot 1$ 重みづけの従来手法}

エンティティペアの重みづけは , 多くのエンティティ ペアから，選択的に重要なぺアを用いて社会ネットワー クの構筑や分析で用いられる大切な技術である. 現在 ， Web からの多くの社会ネットワークの抽出において用い られている方法は，Web 文章におけるエンティティペア の共起の強さによって，関係の強さを推測する方法であ る [Kautz 97, Mika 05, Matsuo 06] . 共起の強さを測るた めに, エンティティ $X$ とエンティティ $Y$ の AND をとり ヒット件数 (共起頻度) を得る, というのが最も単純な 方法であり，次の式で与えられる．

$$
F(X, Y)=|X \cap Y| .
$$

ここで, $|X \cap Y|$ は, エンティティ $X$ とエンティティ $Y$ の AND をとったときのヒット件数を示している . 共起頻 度の他にも, Jaccard 係数 $|X \cap Y| /|X \cup Y|$, Simpson 係
数 $|X \cap Y| / \min (|X|,|Y|)$, ダイス係数 $2|X \cap Y| /(|X|+$ $|Y|)$ ，コサイン $|X \cap Y| / \sqrt{|X||Y|}$ などさまざまな指標 が存在する ${ }^{* 2}$.

検索エンジンのヒット件数を用いたこれらの指標をエ ンティティペアの重みづけに用いることは有用である . しかし, このような指標を単純に関係の強さの推測値と する限界もある.例えば, 共起頻度は, 単独でのヒット 件数が多いエンティティほど有利になる．弚の反対に， Jaccard 係数は単独でのヒット件数が多いエンティティで あるほど，どの人との関係の重みが小さくなる傾向にな る. Simpson 係数は, エンティティのヒット数の最小值 を取っているため, これらの問題はないが, 単独でのヒッ 卜数が, 1 というような極端に少ないエンティティには 特に高い值が出やすい，という欠点がある .これらの問 題に対処するため松尾らは, 次の式で与えられる閾值つ き Simpson 係数を提案している [Matsuo 06] .

$$
F(X, Y)= \begin{cases}\frac{|X \cap Y|}{\min (|X|,|Y|)} & \text { if }|X|>k \text { and }|Y|>k, \\ 0 & \text { otherwise }\end{cases}
$$

しかし , これらのエンティティペアの共起に基づく重み の值を，エンティティペア間の重みの比較に用いた場合， 必ずしも上手くいくとは限らない，例えば，「Google」と $\ulcorner$ Eric Schmidt」という COMPANY-CEO の関係の Simpson 係数による重みと「Adobe Systems」と「Bruce Chizen」 という同じく COMPANY-CEO の関係の Simpson 係数に よる重みは, ほとんど同じであるが， 3 章の評価実験でも 示すように，GGoogle」と「Eric Schmidt」という関係の 方が一般的に良く知られている.このように，どのくら い一般的に知られているかという視点に基づいて，エン ティティペア間の重みづけを行うことができれば，さら に有用なネットワークを構筑できるようになると考える .

\section{$2 \cdot 2$ 提案手法のアイディア}

本論文では, 検索エンジンを用いて，エンティティペア の間のある特定の関係に応じた関係の重みづけをする方 法を提案する.提案手法の基本的なアイディアは , Web を 巨大な連想辞書と見なし，検索エンジンを用いてエンティ ティ間の関係の重みづけに利用する，ということである． 提案手法のアイディアを示すのが図 1 である.エンティ ティペア $(X, Y)$ が与えられたときに, エンティティ $X$ と， エンティティ $Y$ を連想されるようなキーワードをクエリと したときの検索結果の上位に , もう片方のエンティティ $Y$ か現れるか否かを通して重みづけを行う. 弚の際， $Y$ が検 索結果の上位に現れることを, 本論文ではエンティティが 「引き出される」と呼ぶ . さらに, $X$ から $Y$ を連想させ るような語を連想語と呼心゙こととする . 図 図 1 中のネッ トワークは, エンティティペアの連想語によって引き出さ

$* 2|X|,|Y|$ は光れぞれ $\mathrm{X}, \mathrm{Y}$ の単独ヒット件数， $|X \cup Y|$ は， OR をとったときにヒット件数を兴れす。 
れる関係を視覚化したものである .この例では,「Apple」 というエンティティから「Steve Jobs」,「iPhone」という

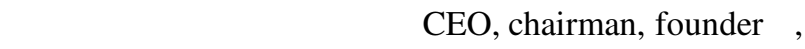
(multi touch, music, phone) という連想語を通して引き 出されると考える.このように「Apple」と「Steve Jobs」， $\ulcorner$ Apple」と「iPhone」といった一般的に良く知られてい る関係は，連想語とともにクエリとして用いることによっ て , 片方のエンティティからもう片方のエンティティを 検索エンジンを用いて, 引き出せる関係になっていると 言うことができる.したがって, 提案手法の 1 つ目の仮 説は以下である

仮説 1 強い関係は, エンティティ $X$ と連想語をクエ リとして用いたときに，弚の検索結果の上位に，エンティ ティ $Y$ か現れる。

次に，たとえエンティティ $X$ と連想語を用いて，エン ンティティ $Y$ が検索結果の上位に表れたとしても，連想 語が一般的で無い場合は，エンティティペアの関係が強 いとは言いがたい，例えば，「CEO」という一般的な連想 語を用いて「Apple」から「Steve Jobs」が引き出された 場合の方が，「Silicon Valley entrepreneur」という限定的 な連想語を用いて引き出された場合よりも関係か強いと は言いがたい，さらに，同じ連想語を用いて引き出され る2つのエンティティペアを考えた場合はどうであろう か? 例えば,「Apple」と「CEO」から 「Steve Jobs」が引 き出される場合と「Viacom」と「CEO」から，「Sumner Redstone」が引き出される場合に，これらの関係の重み が同じとは言いがたい．したがって，2つ目の仮説は以 下である

仮説 2 より一般的な連想語でエンティティ $X$ からエ ンティティ $Y$ が引出され，さらに，人々によって多く 語られているエンティティから引き出される方が関係が 強い。

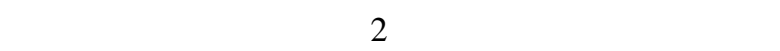
け手法を構築する．なお，これらの仮説は， 3 章の評価 実験によって検証する .

\section{$2 \cdot 3$ 提案手法の詳細}

図 2 に提案手法の流れを示す.エンティティペア $(X$, $Y)$ と， $m$ 個の連想語 $R=\left\{r_{1}, r_{2}, \ldots, r_{i}, \ldots, r_{m}\right\}$ が与え られているときに，まず，検索エンジンを利用して，エン ティティ $X$ と連想語 $r_{i} \in R$ をクエリとした検索を行い， 検索結果トップ $k$ 個のWeb ページを取得する ${ }^{* 3}$. 取得し た Webページに対して , エンティティYが Web ページ中 の文字列として表れているか否かを調べる．Webページ のもつインデックス集合の大きさを $N^{* 4}$, エンティティ

\footnotetext{
*3 検索エンジンとして Yahoo! (http://www.yahoo.com) を利用 した.

*4 Yahooの公式ブログでのインデックス数を参考に $N=192$ 億 とした (http://ysearchblog.com/2005/08/08/our-blog-is-growingup-and-so-has-our-index/)
}

表 1 連想語 (CEO, chairman, founder) を用いた提案手法による関 係の重み .

\begin{tabular}{l|l|r}
\hline$X$ & $Y$ & 重み \\
\hline Microsoft & Bill Gates & 18.6382 \\
Microsoft & Larry Page & 5.0459 \\
\hline Google & Larry Page & 17.0762 \\
Google & Jerry Yang & 5.3793 \\
\hline Yahoo! & Jerry Yang & 17.1226 \\
Yahoo! & Bill Gates & 0 \\
\hline
\end{tabular}

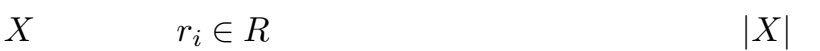
$\left|r_{i}\right|$ として表す.

次に，エンティティペア $(X, Y)$ の関係の重みを次の 式で計算する．

$$
W(X, Y)=\frac{1}{m} \sum_{i=1}^{m} \delta\left(X \mid Y, r_{i}\right) \cdot\left|r_{i}\right| \cdot \frac{|X|}{N} .
$$

ここで, $\delta\left(X \mid Y, r_{i}\right)$ は,検索結果のトップ $k$ ページ以内 にエンティティ $Y$ が含まれているか否かを表し，以下の 式で与えられる．

$\delta\left(X \mid Y, r_{i}\right)= \begin{cases}1 & \text { 検索結果トップ } k \text { 以内に } Y \text { が含まれる } . \\ 0 & \text { それ以外 }\end{cases}$

関数 $W(X, Y)$ は, 仮定 1 に基づき, ヒット数の多い連 想語であるほうが一般的と見なし，一般的である連想語 によって，エンティティ $X$ からエンティティ $Y$ をき出 すことができるほど大きい值が与えられる．同時に，エ ンティティXのヒット数が多ければ多いほど, 值が大き くなる .これは，ヒット数が多いエンティティ $X$ である ほど，対象とするエンティティ $Y$ を引き出すのが難しく なるという，前章で述べた仮定 2 に基づいている．

エンティティペア $(X, Y)$ の重みづけを考える場合， $X$ をクエリとして用いる場合と， $Y$ をクエリとして用いる 場合の 2 通り考えられる . 乥こで，次の式で与えられる これらの合計を全体の重みとする．

$$
F(X, Y)=W(X, Y)+\alpha W(Y, X) .
$$

ここで， $\alpha$ は，光れぞれの重みの影響度合いを調整する ものである .

提案手法を用いた例として，COMPANY-PERSON関係

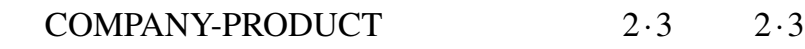

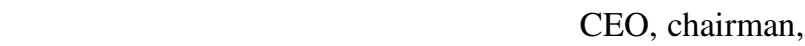
founder) と (product, play, game) である. 検索結果の トップ 5 位以内に入っているか否か $(k=5)$ とした . $2 \cdot 3$ 節では, (Microsoft, Bill Gates), (Google, Larry Page), (Yahoo!, Jerry Yang) のような実際に会社の CEO であっ たり, founderであったりする関係の重みか強くなってい る.弚れに対し，この例で用いた連想語を通じての関係 か強いとは言いがたい (Microsoft, Larry Page), (Google, 
表 3 CEO-COMPANY の関係インスタンス

\begin{tabular}{l|l|r}
\hline CEO & COMPANY & スコア \\
\hline Terry Semel & Yahoo! & 9 \\
\hline Eric Schmidt & Google & 20 \\
\hline Steve Ballmer & Microsoft & 17 \\
\hline Lawrence Ellison & Oracle & 8 \\
\hline Steve Jobs & Apple & 21 \\
\hline John Chambers & Cisco Systems & 6 \\
\hline Kevin Rollins & Dell & 6 \\
\hline James Tobin & Boston Scientific & 6 \\
\hline Frederick Smith & Fedex & 6 \\
\hline John Thompson & Symantec & 8 \\
\hline Sumner Redstone & Viacom & 6 \\
\hline Kenneth Chenault & American Express & 7 \\
\hline Bruce Chizen & Adobe Systems & 8 \\
\hline Samuel Palmisano & IBM & 8 \\
\hline Brian Roberts & Comcast & 7 \\
\hline Jeff Bezos & Amazon & 15 \\
\hline Jeff Kindler & Pfizer & 9 \\
\hline Mark Zuckerberg & Facebook & 13 \\
\hline George David & United Technologies & 6 \\
\hline Paul Otellini & Intel & 7 \\
\hline & & \\
\hline
\end{tabular}

表 2 連想語 (product, play, game) を用いた提案手法による関係の 重み。

\begin{tabular}{l|l|r}
\hline$X$ & $Y$ & 重み \\
\hline Nintendo & Wii & 11.7397 \\
Nintendo & GameBoy & 9.7955 \\
Nintendo & Famicom & 6.5837 \\
\hline Sony & Playstation & 12.0381 \\
Sony & Walkman & 9.7110 \\
Sony & BRAVIA & 8.6037 \\
\hline Microsoft & Windows & 26.4194 \\
Microsoft & Office & 26.0616 \\
Microsoft & Xbox & 25.4599 \\
\hline
\end{tabular}

Jerry Yang) , (Yahoo!, Bill Gates) といった関係の重みは 小さく求められている.また，2·3 節では，3つの会社と 会社か販売している商品を例として用いた . Nintendoの 例では，Wii との関係が最も高くなっており，GameBoy やFamicom といった一世代前に流行した商品との，Web における話題性の違いを反映している結果が見て取れ る . Microsoft の例では, (product, play, game) といった , ゲーム機器に関する連想語を用いているにも関わらず， Microsoft 製のゲーム機器である Xbox よりも，Windows や Office といった製品との関係の方が強いという結果 になっており，Microsoft の主要製品である Windowsや Office との摇るぎない関係の強さか現れた結果となって いる .
表 4 PERSON-FIELD の関係インスタンス

\begin{tabular}{l|l|r}
\hline PERSON & FIELD & スコア \\
\hline Aristole & Philosoper & 24 \\
\hline Tiger Woods & Golf & 24 \\
\hline Garry Kasparov & Chess & 18 \\
\hline Issac Newton & Physics & 24 \\
\hline Sachin Dendulkar & Cricket & 6 \\
\hline Maria Sharapova & Tennis & 23 \\
\hline Venus Williams & Tennis & 21 \\
\hline Carl Lewis & Atheletics & 23 \\
\hline Roger Dederer & Tennis & 16 \\
\hline Andre Agassi & Tennis & 23 \\
\hline Albert Einstein & Physics & 23 \\
\hline Carl Friedrich Gauss & Mathematics & 20 \\
\hline Pele & Soccer & 24 \\
\hline Shane Warne & Cricket & 6 \\
\hline Henri Poincare & Mathematics & 15 \\
\hline Ian Thorpe & Swimmer & 22 \\
\hline Richard Feynman & Physics & 22 \\
\hline Lata Mangeshkar & Singer & 6 \\
\hline Cristian Ronaldo & Football & 21 \\
\hline Max Planck & Physics & 16 \\
\hline & &
\end{tabular}

\section{3. 評 価 実 験}

提案手法の有効性を示すために，評価実験を行なった． COMPANY-CEO , PERSON-FIELD , PERSONBIRTHPLACE , HUSBAND-WIFE 4つのタイプの関 係エンティティペアを対象とした . 各タイプに対し， Wikipedia，ニュース記事を参照しながら，人手で午れ光 れ 20 個の関係インスタンスを取得し評価対象データと した．表 3 , 表 4 , 表 5 , 表 6 に，実験に用いた各関係の 20 個の関係インスタンスを示す . 各表のスコアは以下で 述べる被験者による評価の合計スコアを示している．

連想語は , 各タイプを表す単語をとれ光れ初期キーワー ドとして 3つずつ人手で与え，オンライン類似語辞典 $* 5$ を用いて, 対象とする連想語の数を増加させた . 产の結 果, CEO-COMPANY は, 392 語, PERSON-FIELDは 156 個 ,PERSON-BIRTHPLACEは 189 個 , HUSBANDWIFE は 93 個となった . 各タイプに対して人手で与えた 連想語と，類似語辞典から得られたキーワードの一部抜 粋を表 表 7 に示す.

コンピュータイエンスの研究者 6 人を対象として作成 した重みづけを正解データとし , Jaccard 係数 , Simpson 係数, web-based kernel 手法 [Sahami 06], 提案手法の4 つの手法を用いてエンティティペアの重みづけを行い比 較を行った . 各エンティティペアについて , 各被験者に $\ulcorner$ How would you rate the fame of the relation between the

*5 http://www.thesaurus.com/ 
表 5 PERSON-BRITHPLACE の関係インスタンス

\begin{tabular}{l|l|r}
\hline PERSON & BIRTHPLACE & \multicolumn{1}{|}{ スコア } \\
\hline Franz Kafka & Prague & 10 \\
\hline Andre Agassi & Las Vegas & 7 \\
\hline Charlie Chaplin & London & 17 \\
\hline Luc Besson & New York & 8 \\
\hline Marie Antoinette & Vienna & 15 \\
\hline Albert Einstein & Germany & 18 \\
\hline Carl Friedrich Gauss & Germany & 14 \\
\hline Wolfgang Amadeus Mozart & Austria & 21 \\
\hline Max Planck & Germany & 14 \\
\hline Lucwig Van Beethoven & Germany & 21 \\
\hline Charles Robert Darwin & England & 18 \\
\hline Leonard Da Vinci & Italy & 21 \\
\hline Michelangelo & Italy & 21 \\
\hline William Shakespeare & England & 21 \\
\hline Issac Newton & England & 21 \\
\hline Henri Poincare & France & 11 \\
\hline Pele & Brazil & 22 \\
\hline Garry Kasparov & Russia & 14 \\
\hline Sachin Tendulkar & India & 6 \\
\hline George Gershwin & New York & 12 \\
\hline
\end{tabular}

entity pair?」という質問に対して，以下のようにスコア 付けを行ってもらった .

・ Void, I have never seen/heard about the relation (スコ ア 1)

- Poor, I have seen/heard about the relation a few rare times (スコア 2)

- Medium, I have seen/heard about the relation several times (スコア 3)

- High, I often see/hear about the relation（スコア 4)

被験者 6 人のスコアの合計値を各エンティティペアの正 解重みデータとし，Pearson 相関係数によって評価した .

表 $4 \cdot 2$ 節には, 各手法の重み付けと被験者による正解 データの Pearson 相関係数を示す. 提案手法は, 全ての 関係タイプにおいて, Jaccard 係数, Simpson 係数, およ び web-based kernel の全ての他の手法よりも上回ってい る .このことは, Web におけるエンティティペアの共起 ヒット数よりも, 連想語によって, 検索エンジンで引き 出されるか否かという情報の有効性を示している．すな わち，2 章で述べた仮説 1 の検証と考えることができる .

連想語の一般性と，エンティティの一般性がエンティ ティペアの重みにどのように関係しているかを評価する ために, エンティティを検索結果の上位に引き出す連想 語の数のみを用いて, 正解データとの相関を計算した結 果を，表 $4 \cdot 2$ 節に示す .ここで, 語やエンティティの一 般性をヒット数と定義した．表の通り，一般性を考慮し ている提案手法の結果が大きく上回っており，仮説 2 の
表 6 HUSBAND-WIFE の関係インスタンス

\begin{tabular}{l|l|r}
\hline HUSBAND & WIFE & \multicolumn{1}{|r}{ スコア } \\
\hline Johnny Depp & Venessa Paradis & 9 \\
\hline Bill Gates & Melinda Gates & 13 \\
\hline Tom Cruise & Katie Holmes & 13 \\
\hline Brad Pitt & Angelina Jolie & 18 \\
\hline Andre Agassi & Stefi Graf & 16 \\
\hline David Becham & Victoria Adams & 17 \\
\hline Tom Hanks & Rita Wilson & 12 \\
\hline Joel Madden & Nicole Richie & 6 \\
\hline Asthon Kutcher & Demi Moore & 9 \\
\hline Ben Affleck & Jennifer Garner & 8 \\
\hline Adam & Eve & 24 \\
\hline Mario & Princess Peach & 17 \\
\hline Julius Caesar & Cleopatra & 21 \\
\hline Romeo Montague & Juliet Capulet & 18 \\
\hline Luis XVI & Marie Antoinette & 18 \\
\hline John Lennon & Yoko Ono & 24 \\
\hline Steve Jobs & Laurene Powell & 9 \\
\hline Ben Stiller & Christian Taylor & 6 \\
\hline Barack Obama & Michele Obama & 22 \\
\hline Augustus & Livia Drusilla & 8 \\
\hline & &
\end{tabular}

検証と考えることができる．

\section{4. 議論}

\section{$4 \cdot 1$ 提案手法の有効性と限界}

提案手法では, 重みを計算する際に用いる連想語の選 択が問題となる．本論文の評価実験では人手で初期キー ワードを与えて , 類似辞典を用いて , 候補キーワードセッ 卜を抽出している．しかし，このようにして選ばれたキー ワードセットが全ての各エンティティを引き出す連想語を 含んでいるとは限らない . 検索エンジンへのクエリデー タへのアクセス可能であれば, エンティティと共に用い られている単語を候補キーワードとすることが可能であ るが，一般には必ずしも検索エンジンへのクエリ情報が 入手可能とは限らない，また，森らは，Web を用いて， エンティティに関係する関係語を抽出する方法を提案し ている [森 05] . この方法の基本的はアイディアは，例 えば，CEO関係に関する関係語を調べたいのであれば， $\ulcorner\mathrm{CEO}\lrcorner$ という語をクエリに加える．さらに，「CEO」と 良く共起する語も，CEO関係を把握する手がかりにな として，「CEO」とよく共起する語を Web 上から獲得し ようというものである.さらに，Oyama らは，キーワー ドスパイスという，目的とするページを上位にヒットさ せるために，クエリに適切なキーワードを与える手法の 提案を行っている [Oyama 04] . 今後は, これら樣々な連 想語の選択方法を検討する必要がある． 


\begin{tabular}{|c|c|}
\hline COMPANY-CEO & PERSON-FIELD \\
\hline CEO* & field* \\
\hline chairman* & speciality* \\
\hline head* & profession* \\
\hline captain & subject \\
\hline leadership & occupy \\
\hline executive & role \\
\hline chief & career \\
\hline manager & discipline \\
\hline chair & playground \\
\hline governor & scope \\
\hline brains & domain \\
\hline
\end{tabular}

提案手法は検索エンジンを用いた検索結果とエンティ ティや語のヒット件数を用いた統計的な情報に基づいて 重みを計算しているために，対象となる情報が Web 上 に少ない場合は，高い精度を出すことは難しい，しかし， 樣々なツールの普及により，ユーザは容易に Web コンテ ンツを作成することが可能になっている近年，今後ます ます樣々な情報か増加すれば，提案手法の適用範囲，精 度が広がると考えられる . また, 提案手法では, 検索エン ジンの上位に現れるか否かということが大切な重みづけ の要素となっている．本論文の冒頭でも述べた通り，膨 大な数の Web ページが存在し, 増加し続けている状況の 中 , 検索エンジンの上位に表示されないページにアクセ スすることは難しい . このような背景の中 , 検索結果の 上位に来るか否かという視点を，重みづけに用いるのは 妥当であると考える。

\section{$4 \cdot 2$ 提案手法の応用}

提案手法は, 2 つのエンティティの間の関係の重みを求 めるものであるが，連想語として用いる語を使って，ある コンテキストにおいて特に強い関係を持つエンティティ を探すことに用いることもできる .

コミュニティにおける人の関係の俯敢を考えたり，人と 人をつなぐ関係のパスの発見を効果的に支援するものと して，社会ネットワークが近年注目をあつめている．松尾 らは人間関係を利用した情報支援を目的として，Web 上 から研究者間の恊働関係などを抽出する手法を提案して いる [Matsuo 06] .この手法を利用した学会支援システム POLYPHONET は, 2003 年度から 2008 年度の人工知能 学会全国大会において実際に，全国大会に参加する研究 者を支援するシステムとして使用されている．このよう にエンティティ間の関係に注目した技術は，近年ますま す盛んに研究されている. 提案手法は, POLYPHONET などのシステムにおいて，ある連想語を通じた関係にお いて特に関係の強いつながりを持つ人物の検索を行うな どの応用して利用することができる，例えば，松尾豊と いう研究者と, 特に「人工知能」という連想語を通じた

\begin{tabular}{|c|c|}
\hline PERSON-BIRTHPLACE & HUSBAND-WIFE \\
\hline birthplace* & partner* \\
\hline origin* & couple* \\
\hline root* & spouse* \\
\hline nascency & buddy \\
\hline base & bride \\
\hline foundation & copartner \\
\hline home & pair \\
\hline source & fellow \\
\hline core & duet \\
\hline family & marry \\
\hline town & pal \\
\hline
\end{tabular}

関係において関係のつながりの強い順に出すといった利 用が考えられる.人物一人物といった関係以外にも，人 物一本, 人物一DVD といった樣々な商品との関連の強 さを表す指標としても応用が考えられる .

\section{5. 関 連 研 究}

本研究は,検索エンジンにより 2 つ語の間の関係の強 さを, 連想語を通じて求めるものである. 検索エンジンに より，2つの語の間の強さを求める方法は, Web ページか ら人名を收集し, 人間関係のネットワークを構筑する研究 においてよく用いられている [Kautz 97, Mika 05, Matsuo 06] .これらは, 人名の検索エンジンの共起ヒット数に基 づく指標で関係の強さを求めるものである.

一方，検索エンジンより，関係の強さの中でも，特に 2 つの語の間のセマンティックな類似度を求める研究が行 われている . Sahami らは , 検索エンジンを用いて語のコ ンテキストを含めた 2 つ語の類似度を求める手法を提

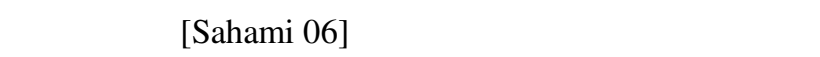
とし, 検索結果の単語を用いて，語を拡張することによ り，語に関係するコンテクストを含めた類似度を求める というアプローチであり, 弚れ光れのクエリの検索結果 に同じ単語が多く含まれている場合は, 類似度が高くな る.しかし，2つの語のコンテキストが似ているからと いって, 関係か強いとは限らない, 実際, 3 章の評価実 験で示されている通り，提案手法の精度が上回っている．

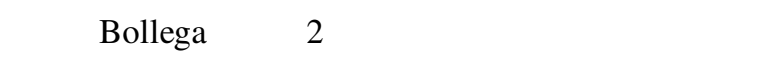
求める手法を提案している [Bollegala 09] .これは, 例え ば. acquisition という関係を持つ (Google, YouTube) と いう語のペアと, (Microsoft, Powerset) という語のペア が与えられたときに, 乥の間の関係類似度を求めるもの であり，2 つの語 (エンティティ) の間の関係の強さを 求める本手法とは目的が異なる.

本研究に関連する一連の研究に, 関連抽出が挙げられ る . 関連抽出とは, ある関係のタイプが与えられたとき に，光の関係を持つインスタンスをタプル $\mathrm{t}=(\mathrm{ei}, \mathrm{rij}$, 
表 8 正解データとのピアソン相関係数の結果

\begin{tabular}{l|c|c|c|c|c}
\hline 関係タイプ & web-based-kernel & web-jaccard & web-simpson & proposed & proposed (only count) \\
\hline CEO-COMPANY & 0.1558 & 0.5037 & 0.4789 & $\mathbf{0 . 8 4 4 2}$ & 0.4325 \\
\hline PERSON-BIRTHPLACE & 0.2293 & 0.08501 & 0.0797 & $\mathbf{0 . 3 6 0 8}$ & 0.1058 \\
\hline HUSBAND-WIFE & -0.2151 & 0.2080 & 0.0371 & $\mathbf{0 . 3 0 7 6}$ & -0.335 \\
\hline PERSON-FIELD & -0.3988 & 0.1580 & 0.1903 & $\mathbf{0 . 3 8 4 9}$ & 0.0101 \\
\hline
\end{tabular}

ej）の form で抽出することを指す . 代表的な研究には， Etzioni らによる KNOWITALL というシステムが挙げら れる [Etzioni 08] また，関係のタイプを指定せず，任意の 関係のタイプの関係インスタンス抽出に拡張した研究と して，TEXTRUNNER がある [Banko 08] .これは，ユー ザが任意に与える関係タイプに対し，インスタンスを抽 出するものである .これにより，Webのような大規模で， 不均一なデータからも，任意の関係タイプに関して，光 のインスタンスを抽出することが可能となっている .こ れら一連の関係抽出の研究は, 関係タイプが与えられた ときに，乥の関係インスタンスをタプルとして，精度良 く抽出することを目的としており，本稿て我々が目的と している，関係の重みづけとは光の目的が異なる．本稿 での研究は, これら沢山の関係インスタンスが抽出され た後, エンティティペア (ei, ej) の関係の重みづけをす る手法, として位置づけることができると言える .

\section{6. む す び}

本論文では，検索エンジンを用いてエンティティペア の間の関係の重みづけを行う手法を提案した .また , エ ンティティと共に連想語をクエリとして用い，検索結果 の上位にもう片方のエンティティが現れるかを通して重 みづけを行うという概念を提案し，評価を通じて従来手 法と比べて有効性を検証した . 提案手法の特徽の1つは， Web を巨大な連想辞書と見なして検索エンジンを用いて， エンティティ間の関係の重みづけに利用している点であ る.これは，樣々な情報か電子化され Webからアクセス できるようになり，検索エンジンの上位に情報が現れる ことか情報にアクセスできる必要不可欠な要素になって いる背景に基づいている。

簡単にWeb に情報を載せるツールの今後のますますの 普及により，Web での情報の増加が予想される．光のよ うな中で, より重要な関係を持つ情報へのアクセスを可 能にし，ユーザのニーズに応じた情報支援を行うことは 今後さらに大切になってくるのではないだろうか .

\section{謝辞}

本研究の一部は, NEDO 産業技術研究助成事業 (若手 研究グラント) により助成を受けて実施しているもので ある.ここに謝意を表す。

\section{$\diamond$ 参 考 文 献 $\diamond$}

[Banko 08] Banko, M. and Etzioni, O.: The Tradeoffs Between Open and Traditional Relation Extraction, in Proceedings of ACL-08: HLT, pp. 28-36, Columbus, Ohio (2008), Association for Computational Linguistics

[Bollegala 09] Bollegala, D., Matsuo, Y., and Ishizuka, M.: Measuring the similarity between implicit semantic relations using web search engines, in WSDM '09: Proceedings of the Second ACM International Conference on Web Search and Data Mining, pp. 104-113, New York, NY, USA (2009), ACM

[Brin 98] Brin, S. and Page, L.: The anatomy of a large-scale hypertextual Web search engine, Comput. Netw. ISDN Syst., Vol. 30, No. 1-7, pp. 107-117 (1998)

[Etzioni 08] Etzioni, O., Banko, M., Soderland, S., and Weld, D. S.: Open information extraction from the web, Commun. ACM, Vol. 51, No. 12, pp. 68-74 (2008)

[Jones 08] Jones, K. B.: Search Engine Optimization: Your Visual Blueprint for Effective Internet Marketing, Visual (2008), ISBN: 0470224487

[Kautz 97] Kautz, H. A., Selman, B., and Shah, M. A.: The Hidden Web, AI Magazine, Vol. 18, No. 2, pp. 27-36 (1997)

[Kudoh 05] Kudoh, T. and Matsumoto, Y.: Applying Cascaded Chunking to Japanese Dependency Structure Analysis, IPSJ SIG Notes, Vol. 2001, No. 20, pp. 97-104 (20010305)

[Kumar 99] Kumar, R., Raghavan, P., Rajagopalan, S., and Tomkins, A.: Trawling the Web for emerging cyber-communities, Comput. Netw., Vol. 31, No. 11-16, pp. 1481-1493(1999)

[Matsuo 06] Matsuo, Y., Mori, J., Hamasaki, M., Ishida, K., Nishimura, T., Takeda, H., Hasida, K., and Ishizuka, M.: POLYPHONET: an advanced social network extraction system from the web, in World Wide Web Conference, pp. 397-406 (2006)

[Matsuo 07] Matsuo, Y., Nakanishi, H., and Hashida, K.: Mining Affiliation of Researchers using a Search Engine, Journal of Japan Society for Fuzzy Theory and Intelligent Informatics, Vol. 19, No. 6, pp. 670-679 (2007)

[Mika 05] Mika, P.: Flink: Semantic Web technology for the extraction and analysis of social networks, Web Semantics: Science, Services and Agents on the World Wide Web, Vol. 3, No. 2-3, pp. 211223 (2005)

[Oyama 04] Oyama, S., Kokubo, T., and Ishida, T.: Domain-Specific Web Search with Keyword Spices, IEEE Trans. on Knowl. and Data Eng., Vol. 16, No. 1, pp. 17-27 (2004)

[Sahami 06] Sahami, M. and Heilman, T. D.: A web-based kernel function for measuring the similarity of short text snippets, in $W W W$ '06: Proceedings of the 15th international conference on World Wide Web, pp. 377-386, New York, NY, USA (2006), ACM

[Sekine 07] Sekine, S. and Nadeau, D.: A survey of named entity recognition and classification, Journal of Linguisticae Investigationes, Vol. 30, No. 1 (2007)

[金 05] 金英子, 松尾 豊, 石塚満: Web 上の情報を用いた企業間 関係の抽出, 知識ベ-スシステム研究会, Vol. 70, pp. 25-30 (2005)

[松尾 07] 松尾豊, 安田 雪: How relations are built within a SNS world: social network analysis on mixi, Transactions of the Japanese Society for Artificial Intelligence. AI, Vol. 22, pp. 531-541 (2007)

[森 05] 森純一郎, 松尾 豊, 石塚満: Web からの人物に関するキー ワード抽出, Vol. 20, pp. 337-345 (2005)

〔担当委員 : 是津 耕司〕 
2009 年 4 月 30 日 受理

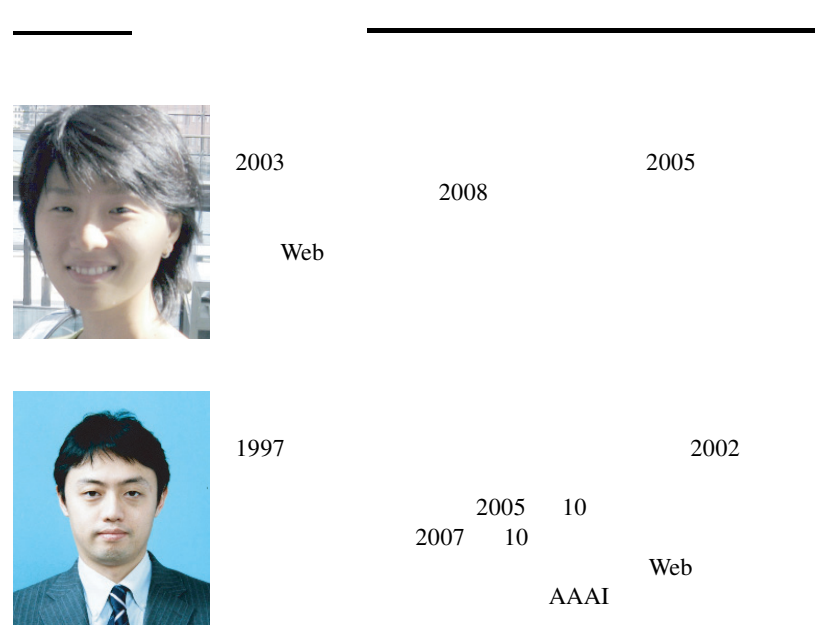

